$1-2020$

\title{
The Effect of Display Size on Ultrasound Interpretation
}

Jamie L. Huot

Thomas Jefferson University, jamie.huot@jefferson.edu

Mark Magee

Thomas Jefferson University, Mark.Magee@jefferson.edu

Arthur Au

Thomas Jefferson University, Arthur.Au@jefferson.edu

Lillian Flashner

Thomas Jefferson University, lillian.flashner@jefferson.edu

Kelly Goodsell

Thomas Jefferson University, Kelly.Goodsell@jefferson.edu

Follow this and additional works at: https://jdc.jefferson.edu/si_me_2022_phase1

See next page for additional authors

Part of the Medical Education Commons

Let us know how access to this document benefits you

\section{Recommended Citation}

Huot, Jamie L.; Magee, Mark; Au, Arthur; Flashner, Lillian; Goodsell, Kelly; Lewiss, Resa E.; and Risler, Zachary, "The Effect of Display Size on Ultrasound Interpretation" (2020). Phase 1. Paper

14.

https://jdc.jefferson.edu/si_me_2022_phase1/14

This Article is brought to you for free and open access by the Jefferson Digital Commons. The Jefferson Digital Commons is a service of Thomas Jefferson University's Center for Teaching and Learning (CTL). The Commons is a showcase for Jefferson books and journals, peer-reviewed scholarly publications, unique historical collections from the University archives, and teaching tools. The Jefferson Digital Commons allows researchers and interested readers anywhere in the world to learn about and keep up to date with Jefferson scholarship. This article has been accepted for inclusion in Phase 1 by an authorized administrator of the Jefferson Digital Commons. For more information, please contact: JeffersonDigitalCommons@jefferson.edu. 
Authors

Jamie L. Huot, Mark Magee, Arthur Au, Lillian Flashner, Kelly Goodsell, Resa E. Lewiss, and Zachary Risler 


\section{SKMC Class of 2022: SI/ME Abstract \\ Word count: 247}

\section{The Effect of Display Size on Ultrasound Interpretation}

Jamie L. Huot, Mark Magee, MD*, Arthur Au, Lillian Flashner, Kelly Goodsell, Resa E. Lewiss, Zachary Risler

Purpose: To assess how display size affects providers' abilities to accurately interpret ultrasound (U/S) videos. U/S has become essential for patient evaluation in the emergency setting. Although newer devices that are smaller in size and affordable place the technology within the pockets of practitioners, it is necessary to assess how smaller size may impact image quality.

Methods: The target learner population for this study includes all practitioners who perform point of care U/S. A prospective convenience sample of emergency providers were randomized to begin on either a phone-sized screen or a laptop-sized screen. Participants answered "Yes" or "No" in response to whether they identified free fluid, above and/or below the diaphragm on each of 50 unique right upper quadrant U/S videos, with 25 displayed per device. Researchers collected data on the speed of interpretation and participants' experiences.

Results and Conclusions: Prior to study initiation, 50\% of participants felt display size would affect accuracy, $42.3 \%$ were unsure, and $7.7 \%$ felt it would not $(n=52)$. The accuracy of interpretation for phone versus laptop display was $87.3 \%$ and $87.6 \%$, respectively $(\mathrm{p}=0.84)$. Mean time spent with phone versus laptop display was 293s and 290s, respectively $(\mathrm{p}=0.66)$. Upon study completion, $48.1 \%$ of participants believed display size affected their ability to interpret the videos, $38.5 \%$ felt it did not, and $13.5 \%$ were unsure. The results of this study show no significant statistical difference in the accuracy of interpretation between screen sizes. 